\title{
Living with Kierkegaard
}

Agnes $\mathrm{H}$ eller

N ew School for Social Research

Kierkegaard meant something very similar to the philosophers and to some significant poets of the 20th century as Feuerbach meant for those second half of the 19. century. The name of feuerbach means «fire creek». The philosophers of the second half of the 19 century desired to leave behind both the philosophical tradition (metaphysics) and the artistic tradition (classicism) with a revolutionary gesture. Kierkegaard himself was one of those thinkers, as was also M arx, Wagner, or N ietzsche. Feuerbach's thinking was/symbolically/ not a waterfall or a broad river to be crossed, but a creek. H e was not significant as a philosopher, but just as a forrunner. Whoever crossed the creek received baptism by fire. But after they have crossed the creek, the creek lost its significance for the giants who crossed it. The philosophers and artists received their baptism through fire, but afterwards they had to become themselves. They went far beyond Feuerbach; yet, they have never forgotten their Feuerbachian inspirations. Still, they constantly reproached Feuerbach with having stopped at the beginning and never having finished the work he firts begun.

O ne among those who crossed the feuerbachian creek, Kierkegaard, became himself one of the significant sources for the thinkers and for (some) poets from the turn of the century onwards. Kierkegaard's name means «churchyard/ churchgarden/». A churchyard is a peaceful garden, one can sit there, contemplate, rumiate. Yet it is also a graveyard. The most significant membres of a community are normally buried there. The representative thinkers of 20th century do not cross the firecreek any longer. If they still do it, they will abandon «baptism» by Kierkegaard. Still, this churchyard/graveyard, just as a century before the fire creek, excerted a never fading influence even on those who have left it behind. Philosophers sit there are thinking, they interpret also tradition, the significant philosophers who are buried there.

$\mathrm{H}$ eidegger writes that three spiritual events excerted the greatest influence on his youth. Firts, the German publication of Kierkegaard's works, second, 
the collected poetry of $\mathrm{H}$ ölderlin, third, the publication of $\mathrm{N}$ ietzsche's (spatious) book T heW ill to Power. Lukács - beforehe became inspired by M arxwas deeply touched by Kierkegaard. He wrote one of his first essays on Kierkegaard's story with Regine $\mathrm{O}$ Isen and its philosophical implications. From Weber to Wittgenstein, from Kafka to Ingmar Bergman, one can hardly see influential authors who would have never been touched by the fresh which biew from the churchyard of Copenhagen.

Contrary to Feuerbach, Kierkegaard was one of the greatest and most significant thinkers of the previous century. N one of the modern thinkers went beyond him. Still, the story of his influence resembles very much on that of Feuerbach. He had no students, no «followers» in a strict sense. H e inspired independent thinkers and not epigons. There was never a K ierkegaard/school, even less a kind of Kierkegaardianism. Frequently, even his debtors did mininize his influence. Heidegger borrowed several great ideas from Kierkegaard without admitting it or, perhaps, without even realizing it. At one point he said that Kierkegaard was not a philosopher, rather a «religious author». In fact, H eidegger's essay «T he end of philosophy and the task of thinking» was sent as a contribution to a conference on K ierkegaard in Paris, 1968, which was one of the most significant conferences in the postW W 2 in Europe. Great thinkers of our century, among others Sastre, Ricœur and Lévinas, paid here tribute to Kierkegaard and to his legacy.

Kierkegaard himself would be most happy with his development. For him philosophy was identical with Cartesian metaphysics, and with $\mathrm{Hegel}$ and Schelling, the last philosophy with the recollection of the mere spectator. The task of thinking was thinking existence. He preferred to speak of the «existing thinker», of the «exister» who is thinking existence. The exister can be a religious thinker, but is not necessarily religious in a traditional sense. The writer speaks about his thougts. Thinking religion can be religous practice, but is cannot be communicated. O ne cannot describe (communicate) the Godrelationship. Thinking means to think the three practical attitudes of men/women, the aesthetical, the ethical and the religious. Yet, among them only the ethical can be communicated, although only indirectly, because the religious and the aesthetical can be only approximated. It was Kierkegaard's deepest conviction that truth is subjectivity. And if truth is subjectivity there can be no positive «teaching», even less can there be a system, except for God, in the divine theater. Every «sm» is the misunderstanding of a paradox. Kierkegaard's influence cannot be an «ism». The misunderstanding of K ierkegaard is al ways the understanding of a paradox. Kierkegaard belongs to us, and we to him, without following him. We are just living with him. This is why, so it seems to me, the influence of Kierkegaard, or rather his inspiration, is not limited in time. $\mathrm{H}$ e expresses, not in the content of his thinking - albeit often also in the content- the paradoxicality of the modern/posmodern philosophical world. H is voice will be heard also in the next century. 